\title{
Sensitivity of Brucella spp to tetracycline and its analogues
}

\author{
I. D. FARRELL, P. M. HINCHLIFFE, AND L. ROBERTSON \\ From the Public Health Laboratory, Royal Infirmary, Meadow Street, Preston PR1 6PS
}

SYNOPSIS The sensitivity to eight tetracyclines of 100 strains of brucellae, comprising strains of Brucella abortus, Br. melitensis, and Br. suis, was determined. Demethylchlortetracycline was the most effective against all the groups of brucellae, whereas oxytetracycline and chlortetracycline were the least effective. The mean MIC value for demethylchlortetracycline, doxycycline, lymecycline, and tetracycline was $\leqslant 1 \mu \mathrm{g} / \mathrm{ml}$. Strains of $B r$. abortus biotype 2 and $B r$. suis were the most sensitive strains examined.

Tetracyclines are the most effective of the chemotherapeutic agents in the treatment of brucellosis (Spink, 1964; Rizzo-Naudi et al, 1967). Robertson et al (1973) have shown that strains of Brucella abortus are almost uniformly sensitive to tetracycline, and the minimum inhibitory concentration (MIC) values are between four and eight times less than the peak plasma levels. Steigbigel et al (1968), in an extensive study, found significant differences in the in-vitro antimicrobial activity of tetracycline and its various chemical analogues.

In this investigation the sensitivity of strains of $B r$. abortus, Br. melitensis, and Br. suis were determined to tetracycline and seven of its analogues. The ditch plate method, described by Robertson $e t$ al (1973) as a suitable method for determining the MIC of various antibiotics to brucellae, was used after further preliminary investigation.

\section{Material and methods}

\section{BRUCELLA STRAINS}

The 100 strains of brucellae used in this study were isolated from human and animal sources. They were classified according to the criteria of Alton and Jones (1967) into 67 strains of Br. abortus, 23 strains of Br. melitensis, and 10 strains of Br. suis, and divided into their biotypes. The strains of $\mathrm{Br}$. abortus were either isolated from cow's milk or cultured from the blood of patients with brucellosis in north-west Lancashire, the strains of Br. melitensis were isolated from patients infected abroad, and the strains of $\mathrm{Br}$. suis were isolated from animal sources abroad.
The strains were grown on serum-dextrose (SD) agar, prepared from blood agar base No. 2 (Oxoid) incorporating $5 \%$ horse serum and $1 \%$ dextrose. All plates were incubated in air containing $10 \% \mathrm{CO}_{2}$ at $37^{\circ} \mathrm{C}$ for three days.

\section{TETRACYCLINE SOLUTION}

Stock solutions of the following eight tetracyclines were prepared in $10 \%$ dimethylformamide (DMF): chlortetracycline, demethylchlortetracycline, doxycline, lymecycline, methacycline, minocycline, oxytetracycline, and tetracycline. They were obtained as powders of known potency from Mast Laboratories, Liverpool.

The solutions were prepared as required and sterilized by membrane filtration.

\section{MINIMUM INHIBITORY CONCENTRATION}

OF THE CONTROL STRAIN

The WHO prototype Br. abortus biotype 2 was used as the control strain and the MIC of each tetracycline was determined as follows:

A series of two-fold dilutions of each of the tetracyclines was prepared in SD agar plates ranging from $4 \mu \mathrm{g} / \mathrm{ml}$ to $0.1 \mu \mathrm{g} / \mathrm{ml}$. Control plates were prepared containing the highest proportion of DMF used in the antibiotic plates, that is, 1 in 200 . A primary suspension of the control strain was prepared in $0.1 \%$ peptone water from a three-day SD agar plate to give approximately $5 \times 10^{8}$ colony-forming units per $\mathrm{ml}$.

The MIC was taken as the lowest concentration of antibiotic which completely inhibited growth or which allowed only a small number of discrete colonies to grow when the surface of the antibiotic 
plate was inoculated with approximately $10^{7}$ brucellae.

\section{DITCH PLATE METHOD}

\section{Calibration of regression lines}

SD agar was poured into $90 \mathrm{~mm}$ flat-bottomed plastic Petri dishes, and, when set, a $15 \mathrm{~mm}$ wide strip of agar was removed along the diameter of each plate. The appropriate concentration of antibiotic was added to molten SD agar at a temperature of $48^{\circ}$ to $50^{\circ}$ in a ratio of one part antibiotic to 19 parts of medium, and this SD-antibiotic agar was used to fill the ditches.

The suspension of the control strain was inoculated onto a series of ditch plates containing two-fold dilutions in the range $160 \mu \mathrm{g} / \mathrm{ml}$ to $10 \mu \mathrm{g} / \mathrm{ml}$ of oxytetracycline and $20 \mu \mathrm{g} / \mathrm{ml}$ to $0.6 \mu \mathrm{g} / \mathrm{ml}$ of the other tetracyclines.

A regression line of the form $y=m x+c$, which described the relation between the logarithm of the concentration of antibiotic (y) and the size of the inhibition zone in millimetres $(x)$, was calculated for each tetracycline by the least squares method (Mosteller et al, 1973).

\section{MIC of the 100 strains under test}

All strains were inoculated onto two ditch plates containing a high and low concentration of antibiotic respectively. This ensured that, whatever the sensitivity of the strain, a measurable zone would be obtained on at least one of the ditch plates. The concentrations in the ditches were $20 \mu \mathrm{g} / \mathrm{ml}$ and 10 $\mu \mathrm{g} / \mathrm{ml}$ for chlortetracycline, oxytetracycline, and methacycline and $10 \mu \mathrm{g} / \mathrm{ml}$ and $1.25 \mu \mathrm{g} / \mathrm{ml}$ for the other tetracyclines.

Five brucella strains were inoculated onto each half of the ditch plate by streaking a loopful of inoculum at right-angles to the ditch from the plate periphery to the nearside edge of the ditch. Thus each ditch plate would accommodate 10 strains without mutual interference between adjacent strains growing on the ditch plate.

The MIC for the test strains was calculated using a sensitivity factor, as previously described by Robertson et al (1973), as follows:

$$
\begin{aligned}
& \text { MIC test strain }= \text { MIC control strain } \times \\
& \text { sensitivity factor. }
\end{aligned}
$$

The sensitivity factor was obtained by subtracting the zone of inhibition of the test strain from that of the control strain, multiplying by the slope $(\mathrm{m})$ of the regression equation, and taking the antilogarithm.

The MIC values obtained by the conventional agar dilution procedure were compared with those obtained by the ditch plate method for 25 strains of brucellae. Both methods gave comparable results and confirmed that the ditch plate method was appropriate for the present investigation.

\section{Results}

The extremes and mean of the MIC values of eack tetracycline are shown in the table for the brucella strains classed according to their species and bio type. These figures indicate that strains of $B r ?$ abortus biotype 2 and $B r$. suis are the most sensitive to all eight antibiotics, while for the remaining biotypes the mean MIC values are similar for any one of the antibiotics. The efficacy of the tetracyclines varied significantly in vitro; oxytetracycline and chlortetracycline were the least effective of the tetracyclines, even for the more susceptible strains. Demethylchlortetracycline was the most effective

\begin{tabular}{|c|c|c|c|c|c|c|c|c|c|c|c|}
\hline \multirow[t]{2}{*}{ Strain } & \multirow[t]{2}{*}{ Biotype } & \multirow{2}{*}{$\begin{array}{l}\text { No. of } \\
\text { strains }\end{array}$} & \multicolumn{8}{|c|}{ Range and mean ${ }^{1}$ of $M I C$ values $(\mu \mathrm{g} / \mathrm{ml})$ of: } & \multirow[b]{2}{*}{$H S D^{2}$} \\
\hline & & & Chlor & Demeth & Doxy & Lyme & Metha & Mino & Oxytet & Tetra & \\
\hline \multirow[t]{6}{*}{ Br. abortus } & 1 & 11 & $\begin{array}{c}1 \cdot 2-4 \cdot 0 \\
(3 \cdot 5)\end{array}$ & $\begin{array}{r}0.2-0.5 \\
(0.40)\end{array}$ & $\begin{array}{c}0 \cdot 2-2 \cdot 0 \\
(1 \cdot 0)\end{array}$ & $\begin{array}{c}0.3-1 \cdot 2 \\
(0.8)\end{array}$ & $\begin{array}{c}0.4-3.0 \\
(1.6)\end{array}$ & $\begin{array}{c}0.5-2.5 \\
(1.6)\end{array}$ & $\begin{array}{c}2 \cdot 0-3 \cdot 7 \\
(3 \cdot 1)\end{array}$ & $\begin{array}{c}0 \cdot 7-1 \cdot 1 \\
(1 \cdot 0)\end{array}$ & 0.45 \\
\hline & 2 & 17 & $\begin{array}{r}0 \cdot 8-1 \cdot 6 \\
(1 \cdot 12)\end{array}$ & $\begin{array}{l}0.04-0 \cdot 2 \\
(0 \cdot 06)\end{array}$ & $\begin{array}{c}0.59-0.9 \\
(0 \cdot 18)\end{array}$ & $\begin{array}{r}0 \cdot 2-0 \cdot 4 \\
(0 \cdot 28)\end{array}$ & $\begin{array}{r}0 \cdot 1-0 \cdot 4 \\
(0 \cdot 25)\end{array}$ & $\begin{array}{r}0 \cdot 1-0 \cdot 8 \\
(0 \cdot 45)\end{array}$ & $\begin{array}{r}1 \cdot 6-2 \cdot 6 \\
(2 \cdot 06)\end{array}$ & $\begin{array}{r}0.2-0 \cdot 6 \\
(0 \cdot 22)\end{array}$ & $0 \cdot 12$ \\
\hline & 3 & 1 & 3.0 & 0.1 & 0.9 & 0.2 & 0.9 & 1.0 & $3 \cdot 3$ & $0 \cdot 7$ & - \\
\hline & 4 & 10 & $\begin{array}{r}1 \cdot 1-4 \cdot 4 \\
(3 \cdot 07)\end{array}$ & $\begin{array}{c}0.04-0.5 \\
(0 \cdot 17)\end{array}$ & $\begin{array}{r}0 \cdot 1-1 \cdot 2 \\
(0 \cdot 78)\end{array}$ & $\begin{array}{r}0 \cdot 5-0 \cdot 7 \\
(0 \cdot 53)\end{array}$ & $\begin{array}{r}0 \cdot 2-4 \cdot 0 \\
(1 \cdot 58)\end{array}$ & $\begin{array}{r}0.4-1 \cdot 6 \\
(1 \cdot 14)\end{array}$ & $\begin{array}{r}1 \cdot 5-3 \cdot 3 \\
(2 \cdot 88)\end{array}$ & $\begin{array}{r}0.7-1 \cdot 0 \\
(0 \cdot 80)\end{array}$ & 0.51 \\
\hline & 5 & 16 & $\begin{array}{r}2 \cdot 0-3 \cdot 6 \\
(3.19)\end{array}$ & $\begin{array}{c}0.08-0.5 \\
(0.39)\end{array}$ & $\begin{array}{r}0.3-1 \cdot 1 \\
(0.69)\end{array}$ & $\begin{array}{r}0.5-1.0 \\
(0.58)\end{array}$ & $\begin{array}{r}1 \cdot 0-2 \cdot 8 \\
(2 \cdot 36)\end{array}$ & $\begin{array}{c}0.5-1.8 \\
(0.93)\end{array}$ & $\begin{array}{r}3 \cdot 3-5 \cdot 0 \\
(3 \cdot 85)\end{array}$ & $\begin{array}{r}0.2-1 \cdot 0 \\
(0.66)\end{array}$ & $0 \cdot 27$ \\
\hline & 9 & 12 & $\begin{array}{r}2 \cdot 0-3 \cdot 4 \\
(2 \cdot 53)\end{array}$ & $\begin{array}{r}0.4-0.6 \\
(0.48)\end{array}$ & $\begin{array}{r}0 \cdot 5-1 \cdot 1 \\
(0 \cdot 78)\end{array}$ & $\begin{array}{r}0.4-1.0 \\
(0.65)\end{array}$ & $\begin{array}{r}1 \cdot 4-2 \cdot 5 \\
(1 \cdot 78)\end{array}$ & $\begin{array}{r}0.4-1.5 \\
(0.91)\end{array}$ & $\begin{array}{r}3 \cdot 1-5 \cdot 4 \\
(3 \cdot 80)\end{array}$ & $\begin{array}{r}0 \cdot 2-1 \cdot 0 \\
(0.70)\end{array}$ & 0.34 \\
\hline Br. melitensis & $1,2,3$ & 23 & $\begin{array}{r}1 \cdot 3-4 \cdot 0 \\
(3 \cdot 05)\end{array}$ & $\begin{array}{c}0.05-0.3 \\
(0.11)\end{array}$ & $\begin{array}{r}0 \cdot 2-1 \cdot 1 \\
(0 \cdot 43)\end{array}$ & $\begin{array}{r}0.5 \cdot 1 \cdot 4 \\
(0.69)\end{array}$ & $\begin{array}{r}0.4-3 \cdot 0 \\
(1.63)\end{array}$ & $\begin{array}{c}0 \cdot 1-3 \cdot 0 \\
(0 \cdot 57)\end{array}$ & $\begin{array}{r}2 \cdot 6-5 \cdot 4 \\
(3 \cdot 47)\end{array}$ & $\begin{array}{c}0.6-1 \cdot 4 \\
(0.88)\end{array}$ & $0 \cdot 30$ \\
\hline Br. suis & $1,2,3$ & 10 & $\begin{array}{r}0.7-3.6 \\
(1.66)\end{array}$ & $\begin{array}{c}0.03-0.08 \\
(0.05)\end{array}$ & $\begin{array}{c}0.05-0.5 \\
(0 \cdot 18)\end{array}$ & $\begin{array}{r}0.1-0.9 \\
(0.52)\end{array}$ & $\begin{array}{r}0 \cdot 1-1 \cdot 3 \\
(0.59)\end{array}$ & $\begin{array}{r}0.2-0.8 \\
(0.56)\end{array}$ & $\begin{array}{r}1 \cdot 0-4 \cdot 2 \\
(2 \cdot 22)\end{array}$ & $\begin{array}{r}0 \cdot 1-0.8 \\
(0.21)\end{array}$ & 0.50 \\
\hline
\end{tabular}
agent in that the mean MIC was the lowest for each

Table Sensitivity of 100 brucella strains to eight tetracyclines

The mean is shown in parentheses.

2HSD = Honestly significant difference; this allows a pair-wise comparison of the mean MIC values for each of the tetracyclines (Haber and Runyon, 1973). 


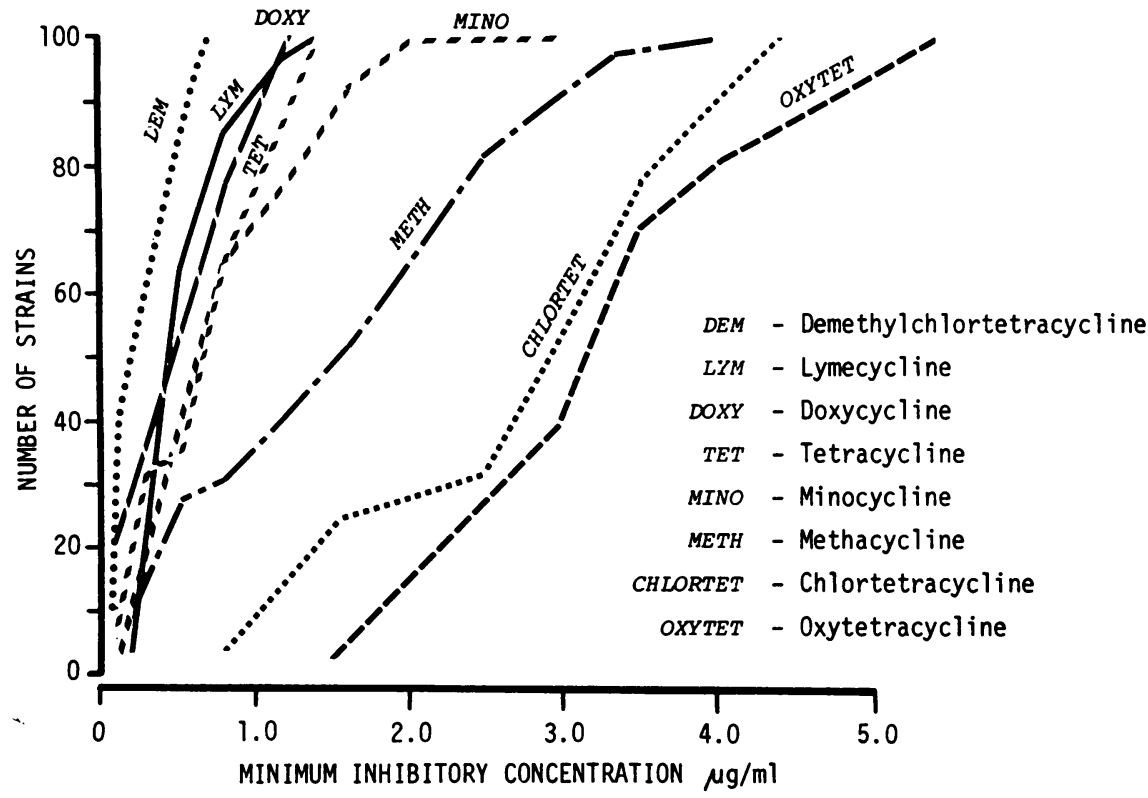

Figure Sensitivity of brucella strains to eight tetracyclines

group of brucellae examined, although the mean MIC values for lymecycline, doxycycline, and tetracycline were always $<1 \mu \mathrm{g} / \mathrm{ml}$.

The cumulative total of brucella strains sensitive to increasing concentrations of the eight antibiotics is depicted in the figure. It can be seen that the tetracyclines form two groups: the first group includes demethylchlortetracycline, lymecycline, doxycycline, tetracycline, and minocycline, and the second includes chlortetracycline and oxytetracycline, methacycline occupying an intermediate position. In the first group, the concentration of antibiotic to which $50 \%$ of the strains were sensitive ranges from $0.2 \mu \mathrm{g} / \mathrm{ml}$ (demethylchlortetracycline) to $0.65 \mu \mathrm{g} / \mathrm{ml}$ (tetracycline), whereas in the second group the range was $2.9 \mu \mathrm{g} / \mathrm{ml}$ (chlortetracycline) to $3 \cdot 7 \mu \mathrm{g} / \mathrm{ml}$ (oxytetracycline).

\section{Discussion}

Tetracyclines are still the chemotherapeutic agents of choice in the treatment of brucellosis (Garrod et $a l, 1973)$ with the possible exception of co-trimoxazole (Hassan et al, 1971; Giunchi et al 1971). In this investigation we have found that the efficacy of the tetracyclines varies significantly in vitro. The method of analysis used was that of one-way analysis of variance, whereby comparison is made between each tetracycline for replicate strains from one brucella type. The honestly significant difference (HSD) is shown in the table for each brucella group. Oxytetracycline and chlortetracycline were the least effective of the tetracyclines, even for the more susceptible strains of $\mathrm{Br}$. abortus biotype 2 and $\mathrm{Br}$. suis. Demethylchlortetracycline was the most effective agent in that the mean MIC value was the lowest for each group of brucella examined. The mean MIC values for lymecycline, doxycycline, and tetracycline were always $\leqslant 1 \mu \mathrm{g} / \mathrm{ml}$, whereas methacycline and minocycline appear to hold an intermediate position. The comparative performance of each tetracycline within the entire brucella sample examined is shown graphically in the figure.

The interpretation of in-vitro antibiotic susceptibilities for the in-vivo clinical situation is complex. The albumin fraction of plasma certainly binds many antibacterial agents, and similar reversible binding may occur with proteins of various tissues and with non-protein macromolecules. Plasma binding can be measured experimentally but results vary. Kunin (1967) reported that tetracycline and demethylchlortetracycline were $24 \%$ and $41 \%$ protein bound respectively, whereas other workers have reported corresponding figures of $65 \%$ and $90 \%$ respectively (Kucers, 1972). Plasma binding is measured in an in-vitro environment which is comparatively static, and often concentrations of antibiotic in excess of expected therapeutic levels are used. However, the in-vivo situation is a complex dynamic system of many competitive activities. The importance of the 
reversibility of plasma binding is reflected in the undoubted effectiveness of agents such as cloxacillin which are known to be highly protein bound. We have chosen to examine the in-vitro efficacy of the various tetracyclines on a weight-to-weight basis and have not attempted to interpret our findings in the light of reported values for serum binding of tetracyclines.

Oxytetracycline was the least effective in our experiments, and chlortetracycline, perhaps because of its instability in vitro, gave similar results. Some of the more recent tetracyclines compared favourably with tetracycline itself and could have a place in the therapy of brucella infections. It is difficult to select any one of this group as the best for clinical use: lymecycline has not had extensive clinical trials, and the reported incidence of photosensitization and gastrointestinal disturbance associated with demethylchlortetracycline may be a disadvantage despite its effectiveness against brucellae. On the other hand, doxycycline and minocycline may be of value because of their slow rate of excretion, which results in prolonged plasma levels.

We are most grateful to Mrs H. E. Tillett for advice and the statistical analysis of our results. We are indebted to Miss A. V. Holt for excellent experimental assistance.

\section{Appendix}

\section{SENSITIVITY FACTOR}

For any one tetracycline concentration let the inhibition zone of the control strain be $S$ millimetres and the zone of the test strain be $T$ millimetres. Then, substituting in the regression equation, the logarithm (y) of this tetracycline concentration $=m S+c$.

The sensitivity factor is $\frac{C t}{C s}$

where $C t=$ the concentration of tetracycline required to give a zone of $T \mathrm{~mm}$ with the test strain, which is the same as that concentration giving a zone of $S \mathrm{~mm}$ with the control strain, namely, ANTILOG $y$, where $y=m S+c$;

and $C s=$ the concentration of tetracycline required to give a zone of $T \mathrm{~mm}$ with the control strain, ie, ANTILOG $y$, where $y=m T+c$.

Therefore $\frac{C t}{C s}=\frac{\text { ANTILOG }(m S+c)}{\text { ANTILOG }(m T+c)}=$

ANTILOG $[(m S+c)-(m T+c)]$ $=$ ANTILOG $m(S-T)$, ie, the sensitivity factor.

Therefore MIC test strain = ANTILOG $m(S-T)$ $\times$ MIC control strain.

Thus the MIC of a test strain was obtained by subtracting its zone of inhibition from that of the control strain, multiplying by the slope $m$, taking the antilogarithm, and multiplying by the MIC of the control strain.

Regression equations obtained for each of the tetracyclines with the WHO prototype $\mathrm{Br}$. abortus biotype 2 were as follows:

Chlortetracycline

Demethylchlortetracycline

Doxycycline

Lymecycline

Methacycline

Minocycline

Oxytetracycline

Tetracycline

$$
\begin{aligned}
& y=0.1 \quad x+0.9 \\
& y=0.1 \quad x-1.6 \\
& y=0.2 x-3.5 \\
& y=0.16 x-1.2 \\
& y=0.17 x-1.7 \\
& y=0.2 x-2.4 \\
& y=1.12 x+0.6 \\
& y=0.1 \quad x-0.97
\end{aligned}
$$

\section{References}

Alton, G. G. and Jones, L. M. (1967). Laboratory technique in brucellosis. Wld Hlth Org. Monogr. Ser., 55, 26.

Garrod, L. P., Lambert, H. P., and O'Grady, F. (1973). Antibiotic and Chemotherapy, 4th edition, p. 321. Churchill Livingstone, Edinburgh and London.

Giunchi, G., de Rosa, F., and Fabiari, F. (1971). Trimethoprim-sulfamethoxazole combination in the treatment of acute human brucellosis. Chemotherapy (Basel), 16, 332- $\overrightarrow{\vec{A}}$ 335.

Haber, A. and Runyon, R. P. (1973). General Statistics, 2nd edition, p. 273. Addison-Wesley, Reading, Mass.

Hassan, A., Erian, M. M., Farid, Z., Hathout, S. D., and Sorensen, K. (1971). Trimethoprim-sulphamethoxazole in acute brucellosis. Brit. med. J., 3, 159-160.

Kucers, A. (1972). The Use of Antibiotics, p. 282. Heinemann, London.

Kunin, C. M. (1967). A guide to the use of antibiotics in patients with renal disease. Ann. intern. Med., 67, 151-158. O

Mosteller, F., Rourke, R. E. K., and Thomas, G. B. (1973). Probability with Statistical Applications, 2nd edition, p. 403. Addison-Wesley, Reading, Mass.

Rizzo-Naudi, J., Griscti-Soler, N., and Ganado, W. (1967). $\frac{D}{O}$ Human brucellosis: an evaluation of antibiotics in the treatment of brucellosis. Postgrad. med. J., 43, 520-526.

Robertson, L., Farrell, I. D., and Hinchliffe, P. M. (1973). S The sensitivity of Brucella abortus to chemotherapeutic N agents. J. med. Microbiol., 6, 549-557.

Spink, W. W. (1964). Host-parasite relationship in brucel- $\mathrm{W}$ losis. Lancet, 2, 161-164.

Steigbigel, N. H., Reed, C. W., and Finaldn, M. (1968). Susceptibility of common pathogenic bacteria to seven tetracycline antibiotics in vitro. Amer.J. med. Sci., 255, 179- $\mathbb{D}$
195. 